\title{
Muricauda lutimaris sp. nov., isolated from a tidal flat of the Yellow Sea
}

\author{
Jung-Hoon Yoon, So-Jung Kang, Yong-Taek Jung and Tae-Kwang Oh
}

Correspondence

Jung-Hoon Yoon

jhyoon@kribb.re.kr
Korea Research Institute of Bioscience and Biotechnology (KRIBB), PO Box 115, Yusong, Taejon, Republic of Korea

\begin{abstract}
A Gram-negative, non-motile, rod-shaped bacterial strain, SMK-108 ${ }^{\top}$, was isolated from a tidal flat of the Yellow Sea in Korea and was subjected to a polyphasic taxonomic investigation. Strain SMK $-108^{\top}$ grew optimally at $\mathrm{pH} 7.0-8.0$ and at $30{ }^{\circ} \mathrm{C}$. It contained MK-6 as the predominant menaquinone. The major fatty acids were iso- $\mathrm{C}_{17: 0} 3-\mathrm{OH}$, iso- $\mathrm{C}_{15: 1}$ and iso- $\mathrm{C}_{15: 0}$. The DNA $\mathrm{G}+\mathrm{C}$ content was $41.1 \mathrm{~mol} \%$. Comparative $16 \mathrm{~S}$ rRNA gene sequence analysis showed that strain SMK-108 ${ }^{\top}$ was related most closely to members of the genus Muricauda, exhibiting 96.6$98.8 \%$ sequence similarity to the type strains of recognized Muricauda species. Strain SMK-108 ${ }^{\top}$ was distinguishable from recognized Muricauda species on the basis of differential phenotypic characteristics, levels of DNA-DNA relatedness and phylogenetic distinctiveness. This organism is thus considered to represent a novel species of the genus Muricauda, for which the name Muricauda lutimaris sp. nov. is proposed. The type strain is SMK-108 ${ }^{\top}$ (=KCTC $22173^{\top}$ =CCUG 55324 $4^{\top}$.
\end{abstract}

The genus Muricauda, a member of the family Flavobacteriaceae in the phylum Bacteroidetes, was proposed by Bruns et al. (2001) for a single species isolated from intertidal sediment, Muricauda ruestringensis. Subsequently, Muricauda flavescens and Muricauda aquimarina were described from a salt lake (Yoon et al., 2005). In the present study, we report on the taxonomic characterization of a bacterial strain (designated SMK$108^{\mathrm{T}}$ ) isolated from a tidal flat sediment of the Yellow Sea in Korea and displaying the basic characteristics of Muricauda strains.

A tidal flat sediment sample collected from Saemankum on the Yellow Sea, Korea, was used as a source for the isolation of bacterial strains. Strain SMK- $108^{\mathrm{T}}$ was isolated by the dilution plating technique on marine agar 2216 (MA; Difco) plates incubated at $25{ }^{\circ} \mathrm{C}$. The type strains of the three recognized Muricauda species were used as reference strains for DNA-DNA hybridization experiments and for investigation of enzyme activities. $M$. ruestringensis DSM $13258^{\mathrm{T}}$ was obtained from the DSMZ, while the type strains of $M$. flavescens and M. aquimarina were from our own institute (Yoon et al., 2005). The morphological, physiological and biochemical characteristics of strain SMK $-108^{\mathrm{T}}$ were investigated by using routine cultivation on MA at $30{ }^{\circ} \mathrm{C}$. Cell morphology was examined by light microscopy (Nikon E600) and transmission electron microscopy (Philips CM-20). The latter technique was

The GenBank/EMBL/DDBJ accession number for the 16S rRNA gene sequence of strain SMK-108 ${ }^{\top}$ is EU156065. also used to search for flagella or the kind of appendages reported for the three recognized Muricauda species (Bruns et al., 2001; Yoon et al., 2005). Cells from exponentially growing cultures were negatively stained with $1 \%(\mathrm{w} / \mathrm{v})$ phosphotungstic acid and the grids were examined after being air-dried. The Gram reaction was determined by using the bioMérieux Gram stain kit according to the manufacturer's instructions. Growth under anaerobic conditions was determined after incubation in a Forma anaerobic chamber on MA and on MA supplemented with potassium nitrate $(0.1 \%, \mathrm{w} / \mathrm{v})$, both of which had been prepared anaerobically under a nitrogen atmosphere. Growth in the absence of $\mathrm{NaCl}$ was investigated by using trypticase soy broth prepared according to the formula of the Difco medium except that $\mathrm{NaCl}$ was excluded. Growth with $\mathrm{NaCl}$ at various concentrations $(1-15 \%, \mathrm{w} / \mathrm{v}$, at $1 \%$ intervals) was investigated in marine broth 2216 (MB; Difco) or trypticase soy broth (Difco). Growth at various temperatures $\left(4,10,15,20,25\right.$ and $28{ }^{\circ} \mathrm{C}$, and $30-40{ }^{\circ} \mathrm{C}$ at $1{ }^{\circ} \mathrm{C}$ intervals) was measured on $\mathrm{MA}$. The $\mathrm{pH}$ range for growth was determined in $\mathrm{MB}$ that was adjusted to various $\mathrm{pH}$ values (4.5-9.5 at intervals of $0.5 \mathrm{pH}$ units). Catalase and oxidase activities and hydrolysis of casein, starch and Tweens 20, 40, 60 and 80 were determined as described by Cowan \& Steel (1965). Hydrolysis of hypoxanthine, tyrosine and xanthine was tested on MA by using the substrate concentrations described by Cowan \& Steel (1965). Hydrolysis of aesculin, gelatin and urea and nitrate reduction were investigated as described by Lányí (1987) with the modification that artificial seawater was used for preparation of media. The artificial seawater contained 
(per litre distilled water) $23.6 \mathrm{~g} \mathrm{NaCl}, 0.64 \mathrm{~g} \mathrm{KCl}, 4.53 \mathrm{~g}$ $\mathrm{MgCl}_{2} \cdot 6 \mathrm{H}_{2} \mathrm{O}$, $5.94 \mathrm{~g} \quad \mathrm{MgSO}_{4} \cdot 7 \mathrm{H}_{2} \mathrm{O}$ and $1.3 \mathrm{~g}$ $\mathrm{CaCl}_{2} .2 \mathrm{H}_{2} \mathrm{O}$ (Bruns et al., 2001). $\mathrm{H}_{2} \mathrm{~S}$ production was tested as described by Bruns et al. (2001). The presence of flexirubin-type pigments was investigated as described by Reichenbach (1992). Susceptibility to antibiotics was investigated on MA plates by using discs (Advantec) containing the following compounds: polymyxin B $(100 \mathrm{U})$, streptomycin $(50 \mu \mathrm{g})$, penicillin $\mathrm{G}(20 \mathrm{U})$, chloramphenicol $(100 \mu \mathrm{g})$, ampicillin $(10 \mu \mathrm{g})$, cephalothin $(30 \mu \mathrm{g})$, gentamicin $(30 \mu \mathrm{g})$, novobiocin $(5 \mu \mathrm{g})$, tetracycline $(30 \mu \mathrm{g})$, kanamycin $(30 \mu \mathrm{g})$, lincomycin $(15 \mu \mathrm{g})$, oleandomycin $(15 \mu \mathrm{g})$, neomycin $(30 \mu \mathrm{g})$ and carbenicillin $(100 \mu \mathrm{g})$. Acid production from carbohydrates was tested as described by Leifson (1963). Utilization of various substrates for growth was determined according to Yurkov et al. (1994). Enzyme activities were determined by using the API ZYM system (bioMérieux).

Table 1. Differential phenotypic characteristics between strain SMK $-108^{\top}$ and recognized Muricauda species

Taxa: 1, strain SMK-108 ${ }^{\mathrm{T}}$; 2, M. ruestringensis (data from Bruns et al., 2001; Yoon et al., 2005); 3, M. flavescens (Yoon et al., 2005); 4, M. aquimarina (Yoon et al., 2005). +, Positive; -, negative; w, weakly positive. All are Gram-negative, non-spore-forming rods. All are positive for the following characteristics: presence of oxidase, alkaline phosphatase, esterase lipase (C8), leucine arylamidase, valine arylamidase, cystine arylamidase, $\alpha$ glucosidase and $\mathrm{N}$-acetyl- $\beta$-glucosaminidase activities, hydrolysis of aesculin, tyrosine and Tween 20, utilization of fructose, cellobiose, sucrose and mannose and acid production from D-fructose, melibiose, Dglucose, D-mannose, cellobiose, lactose, sucrose, maltose, trehalose and raffinose. All are negative for the following characteristics: growth without $\mathrm{NaCl}$ and at $4{ }^{\circ} \mathrm{C}$, nitrate reduction, $\mathrm{H}_{2} \mathrm{~S}$ production, presence of lipase (C14), $\alpha$-galactosidase, $\beta$-galactosidase, $\beta$-glucuronidase, $\alpha$-mannosidase and $\alpha$-fucosidase activities, hydrolysis of hypoxanthine, starch, urea and xanthine, utilization of acetate, pyruvate, glutamate, butyrate, citrate, lactate, formate, methanol, ethanol, benzoate, L-serine and mannitol and acid production from Dsorbitol, myo-inositol, D-ribose, D-mannitol and L-rhamnose.

\begin{tabular}{|c|c|c|c|c|}
\hline Characteristic & 1 & 2 & 3 & 4 \\
\hline Catalase activity & + & $-{ }^{\star}$ & + & + \\
\hline Facultative anaerobic growth & + & + & - & - \\
\hline Optimal growth temperature $\left({ }^{\circ} \mathrm{C}\right)$ & 30 & $20-30$ & $30-37$ & $30-37$ \\
\hline \multicolumn{5}{|l|}{ Hydrolysis of: } \\
\hline Casein & + & - & - & - \\
\hline Gelatin & + & - & - & - \\
\hline Tweens 40,60 and 80 & - & + & + & + \\
\hline \multicolumn{5}{|l|}{ Enzyme activity (API ZYM) $\dagger$} \\
\hline Esterase (C4) & + & - & + & + \\
\hline Trypsin & - & - & $\mathrm{W}$ & + \\
\hline$\alpha$-Chymotrypsin & + & - & + & + \\
\hline Acid phosphatase & + & + & - & + \\
\hline Naphthol-AS-BI-phosphohydrolase & + & + & - & + \\
\hline$\beta$-Glucosidase & + & + & - & + \\
\hline \multicolumn{5}{|l|}{ Utilization of: } \\
\hline Glucose & + & - & + & + \\
\hline Lactose & - & + & + & + \\
\hline Raffinose & - & + & + & + \\
\hline Malate & - & + & - & - \\
\hline Succinate & - & + & + & + \\
\hline Alanine & - & + & - & - \\
\hline L-Arginine & - & + & - & - \\
\hline \multicolumn{5}{|l|}{ Acid production from: } \\
\hline D-Xylose & - & + & - & - \\
\hline L-Arabinose & + & + & - & - \\
\hline Melezitose & + & + & + & - \\
\hline D-Galactose & + & + & - & - \\
\hline DNA G $+C$ content $(\mathrm{mol} \%)$ & 41.1 & 41 & $45.2-45.4$ & $44.1-44.2$ \\
\hline
\end{tabular}

*Negative in Bruns et al. (2001), but positive in Yoon et al. (2005).

$\dagger$ All API ZYM data are for the type strains from the present study. 
Cell biomass for DNA extraction and for isoprenoid quinone analysis was obtained from cultivation in $\mathrm{MB}$ at $30{ }^{\circ} \mathrm{C}$. Chromosomal DNA was isolated and purified according to the method described by Yoon et al. (1996), with the exception that RNase T1 was used in combination with RNase A to minimize contamination by RNA. The 16S rRNA gene was amplified by PCR by using two universal primers as described previously (Yoon et al., 1998). Sequencing of the amplified 16S rRNA gene and phylogenetic analysis were performed as described by Yoon et al. (2003). Isoprenoid quinones were analysed according to Komagata \& Suzuki (1987) by using reversed-phase HPLC. For cellular fatty acid analysis, cell mass of strain SMK- $108^{\mathrm{T}}$ was harvested from MA plates after cultivation for 3 days at $30{ }^{\circ} \mathrm{C}$. The fatty acids were extracted and fatty acid methyl esters were prepared according to the standard protocol of the MIDI/Hewlett Packard Microbial Identification System (Sasser, 1990). The DNA G+C content was determined by the method of Tamaoka \& Komagata (1984) with a modification that DNA was hydrolysed by using nuclease P1 (Sigma) and the resultant nucleotides were analysed by reversed-phase HPLC. DNADNA hybridization was performed fluorometrically according to the method of Ezaki et al. (1989) by using photobiotin-labelled DNA probes and microdilution wells. Hybridization was performed with five replications for each sample. The highest and lowest values obtained in each sample were excluded, and the means of the remaining three values are quoted as DNA-DNA relatedness values.

Morphological, cultural, physiological and biochemical characteristics of strain SMK- $108^{\mathrm{T}}$ are given in the species description below or are shown in Table 1. The almostcomplete 16S rRNA gene sequence of strain SMK- $108^{\mathrm{T}}$ determined in this study comprised $1481 \mathrm{nt}$, representing approximately $96 \%$ of the Escherichia coli 16S rRNA gene sequence. In the neighbour-joining phylogenetic tree constructed on the basis of $16 \mathrm{~S}$ rRNA gene sequences, strain SMK- $108^{\mathrm{T}}$ fell within the cluster comprising species of the genus Muricauda (Fig. 1). Strain SMK-108 ${ }^{\mathrm{T}}$ exhibited 16S rRNA gene sequence similarity values of $98.8,98.8$ and
$96.6 \%$, respectively, to the type strains of M. ruestringensis, $M$. aquimarina and $M$. flavescens. Sequence similarity values to the type strains of other species used in the phylogenetic analysis were less than $93.7 \%$. The predominant isoprenoid quinone detected in strain SMK- $108^{\mathrm{T}}$ was menaquinone-6 (MK-6) at a peak area ratio of approximately $97 \%$. Strain SMK- $108^{\mathrm{T}}$ had a cellular fatty acid profile that contained large amounts of hydroxy, branched and straight-chain components. The major fatty acids $(>10 \%$ of the total) were iso- $\mathrm{C}_{17: 0} 3-\mathrm{OH}(24.6 \%)$, iso- $\mathrm{C}_{15: 1}(21.3 \%)$ and iso$\mathrm{C}_{15: 0}(14.5 \%)$. This fatty acid profile was similar to those of the three recognized Muricauda species cultivated under the same conditions (Yoon et al., 2005), although there were differences in the proportions of some fatty acids (Table 2). The DNA G $+\mathrm{C}$ content of strain $\mathrm{SMK}-108^{\mathrm{T}}$ was $41.1 \mathrm{~mol} \%$. The chemotaxonomic data and the base composition supported the result of the phylogenetic analysis, suggesting that strain SMK- $108^{\mathrm{T}}$ belongs to the genus Muricauda (Bruns et al., 2001; Yoon et al., 2005). However, strain SMK- $108^{\mathrm{T}}$ exhibited mean DNA-DNA relatedness values of 25,20 and $15 \%$, respectively, to the type strains of $M$. ruestringensis, $M$. aquimarina and $M$. flavescens, indicating that it represents a different genomic species (Wayne et al., 1987). Moreover, strain SMK-108 ${ }^{\mathrm{T}}$ could be distinguished from the three recognized Muricauda species based on differences in phenotypic characteristics (Table 1), including hydrolysis and utilization of some substrates. Therefore, on the basis of the data presented, strain SMK- $108^{\mathrm{T}}$ is considered to represent a novel species of the genus Muricauda, for which the name Muricauda lutimaris sp. nov. is proposed.

\section{Description of Muricauda lutimaris sp. nov.}

Muricauda lutimaris (lu.ti.ma'ris. L. n. lutum mud; L. gen. n. maris of the sea; N.L. gen. n. lutimaris of sea mud).

Cells are non-motile, Gram-negative rods $0.2-0.4 \mu \mathrm{m}$ in diameter and 0.8-5.0 $\mu \mathrm{m}$ long. Cells longer than $10.0 \mu \mathrm{m}$ occasionally occur. Appendages similar to those reported in other Muricauda species occur on some cells. Colonies on MA are circular with regular edges, convex, smooth,

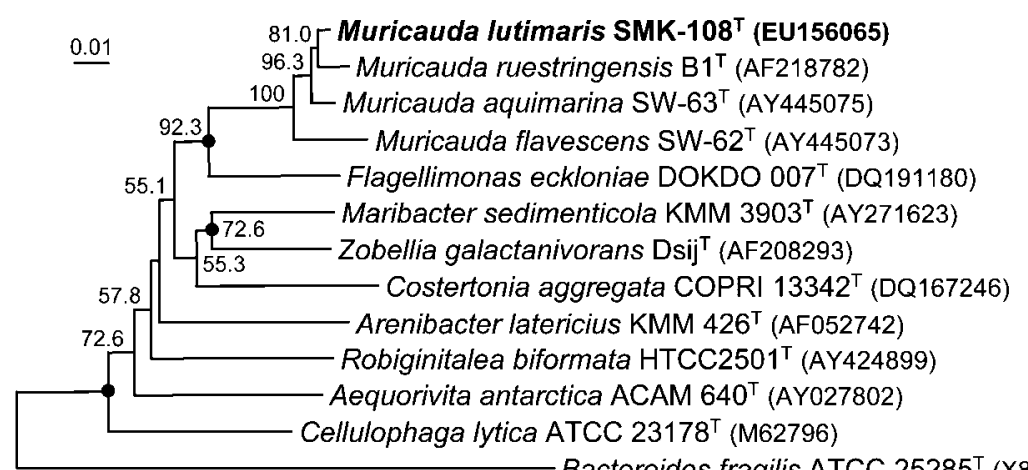

Bacteroides fragilis ATCC $25285^{\top}$ (X83935)
Fig. 1. Neighbour-joining phylogenetic tree based on 16S rRNA gene sequences showing the positions of strain SMK-108 ${ }^{\top}$, recognized Muricauda species and some other related taxa. Bootstrap values (expressed as percentages of 1000 replications) of $>50 \%$ are shown at branch points. Dots indicate that the corresponding nodes were also recovered in trees generated with the maximum-likelihood and maximum-parsimony algorithms. Bacteroides fragilis ATCC $25285^{\top}$ was used as an outgroup. Bar, 0.01 substitutions per nucleotide position. 
Table 2. Cellular fatty acid compositions (\% of total) of strain SMK $-108^{\top}$ and recognized Muricauda species

Strains: 1 , SMK- $108^{\mathrm{T}}$; 2, M. ruestringensis DSM $13258^{\mathrm{T}} ; 3, M$. flavescens $\mathrm{SW}-62^{\mathrm{T}} ; 4$, M. aquimarina $\mathrm{SW}-63^{\mathrm{T}}$. Data for reference strains are from Yoon et al. (2005). -, Not detected. Fatty acids representing less than $0.5 \%$ in all strains were omitted. All strains were cultivated for 3 days on MA at $30{ }^{\circ} \mathrm{C}$. ECL, Equivalent chain length.

\begin{tabular}{|c|c|c|c|c|}
\hline Fatty acid & 1 & 2 & 3 & 4 \\
\hline \multicolumn{5}{|l|}{ Straight-chain } \\
\hline $\mathrm{C}_{15: 0}$ & 7.6 & 13.2 & 12.4 & 5.9 \\
\hline$C_{16: 0}$ & 0.4 & 0.4 & 0.6 & 0.4 \\
\hline \multicolumn{5}{|l|}{ Branched } \\
\hline iso- $\mathrm{C}_{14: 0}$ & - & - & - & 0.6 \\
\hline iso- $\mathrm{C}_{15: 0}$ & 14.5 & 14.7 & 16.4 & 23.7 \\
\hline iso- $\mathrm{C}_{15: 1} \mathrm{G}$ & 21.3 & 20.5 & 19.9 & 21.6 \\
\hline anteiso- $\mathrm{C}_{15: 0}$ & 1.4 & 1.1 & 2.1 & 2.0 \\
\hline iso- $\mathrm{C}_{16: 0}$ & 0.3 & - & 0.6 & 0.5 \\
\hline iso- $\mathrm{C}_{17: 1} \omega 9 c$ & 1.8 & 1.4 & 1.3 & 1.5 \\
\hline \multicolumn{5}{|l|}{ Unsaturated } \\
\hline $\mathrm{C}_{15: 1} \omega 6 c$ & 0.6 & 0.9 & 0.9 & 0.9 \\
\hline $\mathrm{C}_{17: 1} \omega 6 c$ & 0.9 & 1.0 & 0.5 & 0.5 \\
\hline $\mathrm{C}_{17: 1} \omega 8 c$ & 0.5 & 0.7 & 0.4 & - \\
\hline \multicolumn{5}{|l|}{ Hydroxy } \\
\hline $\mathrm{C}_{15: 0} 2-\mathrm{OH}$ & 0.4 & 0.5 & 0.6 & 0.2 \\
\hline $\mathrm{C}_{15: 0} 3-\mathrm{OH}$ & 2.6 & 1.8 & 1.0 & 1.4 \\
\hline iso- $\mathrm{C}_{15: 0} 3-\mathrm{OH}$ & 7.8 & 4.6 & 4.7 & 5.2 \\
\hline $\mathrm{C}_{16: 0} 3-\mathrm{OH}$ & 0.5 & 0.4 & 0.8 & 0.6 \\
\hline iso- $\mathrm{C}_{16: 0} 3-\mathrm{OH}$ & 4.0 & 1.7 & 2.9 & 4.0 \\
\hline $\mathrm{C}_{17: 0} 2-\mathrm{OH}$ & 1.4 & 0.7 & 1.3 & 0.7 \\
\hline $\mathrm{C}_{17: 0} 3-\mathrm{OH}$ & 0.8 & 1.3 & 0.7 & 0.3 \\
\hline iso- $\mathrm{C}_{17: 0} 3-\mathrm{OH}$ & 24.6 & 20.9 & 19.9 & 17.3 \\
\hline Summed feature $3^{\star}$ & 3.3 & 4.2 & 4.1 & 2.3 \\
\hline \multicolumn{5}{|l|}{ Unknown } \\
\hline ECL 11.543 & 0.2 & 0.6 & - & 0.8 \\
\hline ECL 13.565 & 1.7 & 6.5 & 5.4 & 4.8 \\
\hline ECL 16.582 & 1.9 & 1.7 & 1.6 & 1.3 \\
\hline
\end{tabular}

*Summed features represent groups of two or three fatty acids that could not be separated by GLC with the MIDI system. Summed feature 3 comprised $\mathrm{C}_{16: 1} \omega 7 c$ and/or iso- $\mathrm{C}_{15: 0} 2-\mathrm{OH}$.

glistening, yellow and $0.8-1.2 \mathrm{~mm}$ in diameter after 7 days incubation at $30{ }^{\circ} \mathrm{C}$. Optimal growth occurs at $30^{\circ} \mathrm{C}$. Growth occurs at $10-38{ }^{\circ} \mathrm{C}$, but not at 4 or $39{ }^{\circ} \mathrm{C}$. Optimal $\mathrm{pH}$ for growth is 7.0-8.0. Growth occurs at $\mathrm{pH}$ 5.0, but not at $\mathrm{pH} 4.5$. Growth occurs in the presence of up to $10 \%$ $(\mathrm{w} / \mathrm{v}) \mathrm{NaCl}$, but not in the absence of $\mathrm{NaCl}$ or in the presence of more than $11 \%(\mathrm{w} / \mathrm{v}) \mathrm{NaCl}$. Anaerobic growth occurs on MA and on MA supplemented with potassium nitrate. Flexirubin-type pigments are not produced. LArabinose, maltose, trehalose and salicin are utilized, but D-galactose and D-xylose are not. Susceptible to chloramphenicol, novobiocin, tetracycline, carbenicillin, lincomycin and oleandomycin, but not to ampicillin, cephalothin, gentamicin, kanamycin, neomycin, polymyxin
$B$, penicillin $G$ or streptomycin. The predominant menaquinone is MK-6. The major fatty acids ( $>10 \%$ of the total) are iso- $\mathrm{C}_{17: 0} 3-\mathrm{OH}(24.6 \%)$, iso- $\mathrm{C}_{15: 1}(21.3 \%)$ and iso$\mathrm{C}_{15: 0}(14.5 \%)$. The DNA G+C content is $41.1 \mathrm{~mol} \%$ (determined by HPLC). Other phenotypic characteristics are given in Table 1.

The type strain, SMK- $108^{\mathrm{T}}\left(=\mathrm{KCTC} 22173^{\mathrm{T}}=\right.$ CCUG $55324^{\mathrm{T}}$ ), was isolated from a sediment sample collected from a tidal flat at Saemankum, on the Yellow Sea, Korea.

\section{Acknowledgements}

This work was supported by the 21C Frontier program of Microbial Genomics and Applications (grant MG05-0401-2-0) and the Support and Application Project of Biological Resources (grant M10508050004-06N0805-00410) from the Ministry of Science and Technology (MOST) of the Republic of Korea.

\section{References}

Bruns, A., Rohde, M. \& Berthe-Corti, L. (2001). Muricauda ruestringensis gen. nov., sp. nov., a facultatively anaerobic, appendaged bacterium from German North Sea intertidal sediment. Int J Syst Evol Microbiol 51, 1997-2006.

Cowan, S. T. \& Steel, K. J. (1965). Manual for the Identification of Medical Bacteria. London: Cambridge University Press.

Ezaki, T., Hashimoto, Y. \& Yabuuchi, E. (1989). Fluorometric deoxyribonucleic acid-deoxyribonucleic acid hybridization in microdilution wells as an alternative to membrane filter hybridization in which radioisotopes are used to determine genetic relatedness among bacterial strains. Int J Syst Bacteriol 39, 224-229.

Komagata, K. \& Suzuki, K. (1987). Lipid and cell-wall analysis in bacterial systematics. Methods Microbiol 19, 161-207.

Lányí, B. (1987). Classical and rapid identification methods for medically important bacteria. Methods Microbiol 19, 1-67.

Leifson, E. (1963). Determination of carbohydrate metabolism of marine bacteria. J Bacteriol 85, 1183-1184.

Reichenbach, H. (1992). The order Cytophagales. In The Prokaryotes. A Handbook on the Biology of Bacteria: Ecophysiology, Isolation, Identification, Applications, 2nd edn, pp. 3631-3675. Edited by A. Balows, H. G. Trüper, M. Dworkin, W. Harder \& K. H. Schleifer. New York: Springer.

Sasser, M. (1990). Identification of bacteria by gas chromatography of cellular fatty acids, MIDI Technical Note 101. Newark, DE: MIDI Inc.

Tamaoka, J. \& Komagata, K. (1984). Determination of DNA base composition by reversed-phase high-performance liquid chromatography. FEMS Microbiol Lett 25, 125-128.

Wayne, L. G., Brenner, D. J., Colwell, R. R., Grimont, P. A. D., Kandler, O., Krichevsky, M. I., Moore, L. H., Moore, W. E. C., Murray, R. G. E. \& other authors (1987). International Committee on Systematic Bacteriology. Report of the ad hoc committee on reconciliation of approaches to bacterial systematics. Int $J$ Syst Bacteriol 37, 463-464.

Yoon, J.-H., Kim, H., Kim, S.-B., Kim, H.-J., Kim, W. Y., Lee, S. T., Goodfellow, M. \& Park, Y.-H. (1996). Identification of Saccharomonospora strains by the use of genomic DNA fragments and rRNA gene probes. Int J Syst Bacteriol 46, 502-505.

Yoon, J.-H., Lee, S. T. \& Park, Y.-H. (1998). Inter- and intraspecific phylogenetic analysis of the genus Nocardioides and related 
taxa based on 16S rDNA sequences. Int $J$ Syst Bacteriol 48, 187-194.

Yoon, J.-H., Kim, I.-G., Shin, D.-Y., Kang, K. H. \& Park, Y.-H. (2003). Microbulbifer salipaludis sp. nov., a moderate halophile isolated from a Korean salt marsh. Int J Syst Evol Microbiol 53, 53-57.

Yoon, J.-H., Lee, M.-H., Oh, T.-K. \& Park, Y.-H. (2005). Muricauda flavescens sp. nov. and Muricauda aquimarina sp. nov., isolated from a salt lake near Hwajinpo Beach of the East Sea in Korea, and emended description of the genus Muricauda. Int J Syst Evol Microbiol 55, 1015-1019.

Yurkov, V., Stackebrandt, E., Holmes, A., Fuerst, J. A., Hugenholtz, P., Golecki, J., Gad'on, N., Gorlenko, V. M., Kompantseva, E. I. \& Drews, G. (1994). Phylogenetic positions of novel aerobic, bacteriochlorophyll a-containing bacteria and description of Roseococcus thiosulfatophilus gen. nov., sp. nov., Erythromicrobium ramosum gen. nov., sp. nov., and Erythrobacter litoralis sp. nov. Int J Syst Bacteriol 44, 427-434. 